UDC: 811.111:141.2 https://doi.org/10.22190/JTESAP2104703I

Original scientific paper

\title{
IMPACT OF THE COVID-19 PANDEMIC ON HIGHER EDUCATION: THE CASE OF THE REPUBLIC OF SRPSKA
}

\author{
Slavica Išaretović, Vesna Đurović, Zorana Agić \\ Visoka škola "Banja Luka College”, Banja Luka, \\ Bosnia and Hercegovina
}

\begin{abstract}
Pandemic was a serious test for higher education institutions that showed the extent to which professors and students have adopted and used all the advantages of new technology in teaching. This is exactly what this research aims for - assessment and comparison of the performance of students who attended traditional classes before the pandemic, and online and combined during the pandemic. This research will show whether the way of teaching affects class attendance and activity of students. Data were collected from traditional classes (March - July 2019), online classes (March - July 2020) and combined classes (March - July 2021). The main research question in this study is whether there was a difference in the success of students who attended classes in the traditional way, online or by combining these two models. To obtain the results, a t-test of independent samples was used with the calculation of the mean and standard deviation. This relevant research shows which approaches and methods of teaching English for students gives the best results, given the specifics of its implementation and the need for interactivity during teaching.
\end{abstract}

Key words: students' success, Covid 19 pandemic, traditional teaching, online teaching, combined teaching

\section{INTRODUCTION}

Covid-19 pandemic has changed the field of education forever. The invisible enemy forced all instructors, especially those who were technologically illiterate, to start using computers overnight in order to continue teaching their students. Professors and students alike had to adapt to new methods of teaching and learning and find different approaches that were suitable to online teaching (Đurović 2021). Suddenly it became clear how important and significant this new teaching mode is in the time of crisis (Halilović 2020).

Many countries have imposed dramatic policy changes to enforce their rules and regulations, seeking to protect their communities from becoming victims of this pandemic and to ensure continued high levels of productivity and performance (Stawicki, et al. 2020).

The main role of the education is to adapt and direct behavior of the groups and individuals in order to contribute development of the society, interpersonal toleration and maximal development and usage of the skills and knowledge that improve economy and

Submitted July $5^{\text {th }}, 2021$, accepted for publication September $15^{\text {th }}, 2021$

Corresponding author: Slavica Išaretović. Visoka škola "Banja Luka College", Banja Luka, Bosnia and Hercegovina.

E-mail: slavica.isaretovic@blc.edu.ba

(C) 2021 by University of Niš, Serbia | Creative Commons License: CC BY-NC-ND 
economic growth (Zovko 2014) (Dušanić - Gačić and Agić 2021). According to the definition, faculties are in the process of educating independent scientific-educational institutions that have a triple function: they educate highly professional staff for various areas of social life and productive work, organize and improve the appropriate scientific field and form scientific staff (Trnavac and Đorđević 2013).

Pandemic was a serious test for higher education institutions as key institutions of higher education. COVID-19 tested the extent to which professors and students are willing to adopt and use new technologies, by switching to online teaching, which has emerged as the only solution in a situation where the virus has spread unstoppably. It is undeniable that information and communication applications enhanced by Internet technologies have proven to be powerful tools and have played a significant role in the rapid development of online learning (Kurilovas and Kubilinskiene 2020).

The World Health Organization (WHO) declared the outbreak of COVID-19 a global pandemic on March 11, 2020. The term "pandemic" is defined as "an epidemic that occurs worldwide or in a very wide area, crossing international borders and usually affecting large numbers of people" (Doshi 2011).

The virus was first discovered in December 2019 in Wuhan, China, and caused a lasting pandemic (Hui, et al. 2020). The first case was discovered on November 17, 2019 in Hubei, China (Ma 2020). In Bosnia and Herzegovina, the first case of coronavirus was reported in Republic Srpska entity ${ }^{1}$, March 5, 2020. As early as March 10, the Government of the Republic Srpska issued a proclamation that all schools and higher education institutions were to be closed for twenty-one days. As of March 30, a ban and restriction on movement and work, as well as all types of public gatherings, are introduced, and this measure remained in force until April 13. The Republic Headquarters for Emergency Situations only extends the adopted measures, until November 2, when it returns elementary and high school students to school, without limiting the way of teaching at higher education institutions. Most of the faculties and colleges have opted for combined teaching, which is a combination of traditional and online teaching. Online teaching was the solution and the new "normality" of the educational process. New communicative models emerge and become a new normal state of mind (Babić, Muhić and Tica 2021). It has proven to be the best method for students and teachers, especially during the long locking phases (Yusuf 2020). Public and private higher education institutions have realized that online education is the only way to continuously provide quality educational services by minimizing contact to a minimum. What has not been sufficiently researched are the effects of online teaching in the educational process of students and this research is just an attempt to obtain this data, comparative indicators that can serve to improve work with students, regardless of which method we are talking about.

\section{LITERATURE REVIEW}

In developed countries, online teaching was conducted at some colleges and universities even before the pandemic. Studies conducted before the pandemic are available in the literature, comparing the successes of students who followed traditional classroom instruction with the successes of students who followed online instruction. The results of most surveys show that

\footnotetext{
${ }^{1}$ Bosna and Herzegovina is a state constituted of two entities: Republic of Srpska and Federation. Education is the sole responsibility of the entity governments.
} 
there are no significant differences in learning satisfaction and academic success of these groups of students (Soesmanto and Bonner 2019) (Lorenzo-Alvarez, et al. 2019). Some authors suggest that university teachers, with appropriate training and technology support, conduct both traditional and online teaching, with the same efficiency and measurement scales for student scoring and assessment (Tan, et al. 2019). There is an opinion in the literature that the level of academic success in the final exam will be reduced among students who followed online classes due to lack of communication with teachers when they face difficulties in understanding the material (Sintema 2020). This attitude was confirmed in the conducted research, and the results show that the rapidly created methods of online teaching had the effect of reducing student performance compared to the results achieved by following traditional teaching (Nyer 2019). Some authors believe that the primary influence on individual grades in subjects has the average grade of students. Accordingly, students with a higher grade point average performed better in online classes, while students with lower average grades performed better in traditional classes (Cavanaugh and Jacquemin 2015).

The sudden transition to online teaching, after the proclamation of the Covid-19 pandemic, opened a series of questions about the advantages and disadvantages of this way of learning and teaching, about the problems and successes of students that they achieved by following online teaching. Short time and lack of learning resources stand out as key obstacles to the transition to online teaching (Hjelsvold, Bahmani and Loras 2020). However, the results of the research show that there is no statistically significant difference between the success of students who followed traditional and online classes (Said 2021). Students and teachers pointed out the lack of sufficient practice in online teaching, but both quickly adapted and showed a positive attitude towards change (Hjelsvold, Bahmani and Loras 2020). The available research identifies key issues that have arisen due to disruption of traditional education during the pandemic, and they are: inequality and digital divide that emerged during the pandemic, the need for additional assessment and evaluation of methods and the need to switch to formal assessment through harmonized and uncoordinated means and monitoring and control of exams conducted online (Bozkurt, et al. 2020). The challenges of online teaching have also been identified, and they are: availability, accessibility, flexibility, learning pedagogy, lifelong learning and educational policy (Murgatrotd 2020).

It is too early to assess how online teaching during the pandemic will affect education systems around the world, but there are indications that it will have an impact on the introduction of innovation in education. Most of the previously mentioned studies are related to the comparison of traditional and online teaching and cover a short period of time. The authors believe that the results would be more reliable if student success were monitored over a longer period of time. Therefore, this research was conducted using the data of three semesters during which traditional, online and combined classes were conducted.

\section{DATA AND METHODOLOGY}

On the global level, COVID-19 pandemic has caused discontinuation of the education for 1.6 billion children and youth all over the world (United Nations, 2020). Higher education institutions on the Western Balkans were closed, and teaching was suddenly transferred online for more than 600.000 students (World Bank Group, 2020). According to the before mentioned, a study which aim was estimation and comparison of the success of the students who participated to traditional education prior to pandemic, and then online 
and combined education during the pandemic. Besides that, the aim of this research is to determine whether the presence and the activity of the students during teaching process depend on the way of conducting the teaching process.

The research is based on the general hypothesis that there is no significant difference between the successes of students who follow traditional, online or combined classes. Due to the complexity of the research problem, two specific claims will be examined in the paper. According to the first, there is no significant difference between the presence of students in lectures and exercises that accompany traditional, online and combined teaching. According to the second, there is no significant difference between the activities of students who follow traditional, online or combined classes.

A total of seven variables were included in the research: gender of the student (Sex), study direction (Direction), class activity, class attendance (Attendance), total number of points (Total grades), final grade (Grade) and class attendance period (Period).

When assessing the differences in the success of students who attended traditional, online and combined classes, the dependent variable is the total number of points (Total grades), while the remaining variables are independent. When assessing the differences between student attendance and activity during traditional, online, and combined teaching, the dependent variables are Attendance and Class activity, respectively, and the remaining six variables are independent.

The comparison was made on the same subject, which was performed in three different ways (traditional, online and combined) at a private higher education institution in Bosnia and Herzegovina. The authors chose an obligatory subject, English, which is taken by all students, regardless of the field of study. Traditional classes were held in the spring of 2019, online classes in the spring of 2020 (lectures and exercises in the form of meetings on the Microsoft Teams platform, and all materials were available on the mentioned platform and on Moodle), and combined classes in the spring of 2021 (lectures and exercises were held in the classroom and in the form of meetings on the Microsoft Teams platform, and materials were given to students in class and were available on Microsoft Teams and Moodle). It is important to emphasize that the same materials (textbooks, power point presentations, case studies) were used in the lectures and that the tests were approximately at the same level. Regardless of the way of teaching, students had the opportunity to attend two hours of lectures and three hours of exercises per week, or 30 hours of lectures and 45 hours of exercises during the semester. Classes were taught by the same professors.

Student grading was identical in all three cases. The total number of points on the course is 100 , and it represents the sum of points on the final exam (50 points) and points that the student achieved during the semester (50 points). During the semester, students attended lectures and exercises (up to 5 points), participated in class discussions (up to 5 points) and took two colloquia (20 points each, up to 40 points in total). Depending on the total number of points that students had, the subject professors formed the final grade (grade 6: 51-60 points, grade 7: 61-70 points, grade 8: 71 to 8 points, grade 9: 81 to 90 points and grade 10: $91-100$ points). If the student had 50 or less points, it is considered that one did not pass the exam that is the student did not pass the exam.

The data necessary for the research were collected by the subject teachers, and the higher education institution gave its consent for anonymous data analysis and publication of results for academic purposes. Data were collected from traditional classes (March - July 2019), online classes (March - July 2020) and combined classes (March - July 2021). Data were processed using a statistical program IBM SPSS Statistics Version 26. 
The main research question in this study is whether there was a difference in the success of students who attended classes in the traditional way, online or by combining these two models. To obtain the results, a t-test of independent samples was performed with the calculation of the mean value and standard deviation. Furthermore, the Chi-square test method was used to compare the distribution of students' grades for all ways of teaching. The research was conducted as follows: first, a comparison of the success of students who attended traditional and online classes, then a comparison of the success of students who attended online and combined classes, and finally a comparison of students who followed traditional and combined classes. Accordingly, the results of the research are presented.

\section{RESULTS AND DISCUSSION}

In order to get the answer whether there is the difference in the results in students' success that participated different models of classes T-test of independent samples was used. The data were gathered on the success of 505 students, out of which 160 participated traditional classes in classrooms (31.7\% of the total sample), 155 online classes (30.7\% of the total sample), and 190 combined classes, both online and in classroom (37.6\% of the total sample). The largest number of students is on the department Economy (204 students, that is $40.4 \%$ ), followed by the students of the department Informatics (153 students, that is 30.3\%) and Graphic Design (117 students, that is 23.2\%), while the least number of students attend Media and Communication ( 31 students, that is $6.1 \%$ ). Additionally 236 students are male (46.7\%), while 269 students are female $(53.3 \%)$. Data of the sample are gathered using descriptive statistics.

Authors analyzed the points that students collected during the semester and their final grades in order to determine whether the presence and activity on the classes, as well as their success are determined by the form of conducting classes. Correlation of the success is condemned using T-test, and comparison of grade distribution in observed groups is conducted using Chi-square test. The results are given in the following part of the study.

\subsection{Results of the comparison traditional and online education}

During the spring of 2019, students attended only traditional classes in the classroom (160 students), and the average grade they achieved was 8.89 , with a standard deviation of 1,562. A year later, due to the Covid-19 pandemic, students followed only online classes (155 students) and achieved an average grade of 8.43, with a standard deviation of 1,910. The comparison of these two groups of students was performed using the T-test, and the results are given in Table 1.

Table 1. Comparison of student success in traditional and online teaching

\begin{tabular}{|c|c|c|c|c|c|c|c|c|c|}
\hline \multirow{2}{*}{$\begin{array}{l}\text { Assessment } \\
\text { items }\end{array}$} & \multicolumn{3}{|c|}{ Traditional education } & \multicolumn{3}{|c|}{ Online education } & \multirow{2}{*}{$\begin{array}{c}\text { Difference } \\
\text { mean }\end{array}$} & \multirow{2}{*}{$\begin{array}{l}\text { t-Test } \\
\text { value }\end{array}$} & \multirow{2}{*}{$\mathrm{p}$ value } \\
\hline & Mean & St. dev. & $\mathrm{N}$ & Mean & St. dev. & $\mathrm{N}$ & & & \\
\hline & & & 160 & & & & & 1,860 & \\
\hline & & & 160 & 3,79 & & 15 & & & \\
\hline Total grades & 82,01 & 14,924 & 160 & 75,77 & 21,590 & 155 & 6,232 & 2,971 & 0,003 \\
\hline
\end{tabular}

The T-test of independent samples compared the points that students received for attending traditional and online classes. The results show that there was no significant 
difference in the number of points in traditional (Mean $=3.77$, St. dev. $=1.209)$ and online $($ Mean $=3.49$, St. dev. $=1.434)$ teaching. Further, a comparison was made of the number of points students received for activity in traditional teaching (Mean $=3.83$, St. dev. $=$ $0.781)$ and in online teaching (Mean $=3.79$, St. dev. $=1,000)$. The obtained result shows that there was no statistically significant difference $(\mathrm{p}$ value $=0.064)$.

Using the T-test, the total number of points that students achieved during the two observed semesters was compared. The results show that students averaged 82.01 points when they attended classes in the classroom, with a standard deviation of 14,924. In addition, the results show that students scored an average of 75.77 points during online classes, with a standard deviation of 21,590 . Here it can be noticed that there is a statistically significant difference between the number of total points that students achieved during traditional classes and the number of points that they achieved during online classes. Given the fact that a statistically significant difference was found, the magnitude of the impact was determined using the eta square, which represents the proportion of variance in the dependent variable (Total grades) explained by the independent grouping variable, and whose value can be from 0 to 1 . In this case, the eta square is 0.0274 and indicates a small impact, that is, it shows that the teaching model affects the success of students in a very small percentage of $2.74 \%$.

Further, the Chi-square test method was used to compare the distribution of scores for both groups and to determine whether there was a statistically significant difference in the distribution of grades. Table 2 provides an overview of the distribution of grades among students who attended traditional and online classes.

Table 2. An overview of the distribution of grades in traditional and online teaching

\begin{tabular}{|l|l|c|c|c|c|c|c|c|c|}
\hline \multirow{2}{*}{ Period } & \multicolumn{8}{|c|}{ Grade } \\
\cline { 3 - 10 } & 5 & 6 & 7 & 8 & 9 & 10 & Success & Fall \\
\hline $\begin{array}{l}\text { Traditional } \\
\text { education }\end{array}$ & Count & 8 & 13 & 8 & 22 & 18 & 91 & 152 & 8 \\
\cline { 2 - 10 } $\begin{array}{l}\text { Online } \\
\text { education }\end{array}$ & $5,0 \%$ & $8,1 \%$ & $5,0 \%$ & $13,7 \%$ & $11,3 \%$ & $56,9 \%$ & $95 \%$ & $5,0 \%$ \\
\cline { 2 - 10 } & Count & 16 & 26 & 8 & 10 & 15 & 80 & 139 & 16 \\
\hline
\end{tabular}

The result of the chi-square test shows that there is a statistically significant difference between the grades obtained by students who followed traditional classes and students who followed online classes $(\mathrm{N}=315$, Chi-Square $=12,404, \mathrm{df}=5, \mathrm{p}=0,030)$. However, the correlation coefficient (Phi coefficient $=0.198$ ) indicates a small impact, that is, a weak correlation between students' grades and the way they attended classes. Based on the data presented in Table 2, it can be concluded that students achieved better results in traditional teaching.

\subsection{Results of the comparison online and combined education}

Comparing the success of students who attended online classes (155 students) and the success of students who attended combined classes (190 students), it can be concluded that the average grade during online classes is 8.43 (St. dev. 1,910), while the average grade in students who attended combined classes was up to 8.58 (St. dev. 1,681). The results of the comparison are given in Table 3. 
Table 3. Comparison of student success in traditional and online teaching

\begin{tabular}{|c|c|c|c|c|c|c|c|c|c|}
\hline \multirow{2}{*}{$\begin{array}{l}\text { Assessment } \\
\text { items }\end{array}$} & \multicolumn{3}{|c|}{ Online education } & \multicolumn{3}{|c|}{ Combined education } & \multirow{2}{*}{$\begin{array}{c}\text { Difference } \\
\text { mean }\end{array}$} & \multirow{2}{*}{$\begin{array}{l}\mathrm{t} \text {-Test } \\
\text { value }\end{array}$} & \multirow{2}{*}{$\mathrm{p}$ value } \\
\hline & Mean & St. dev. & $\mathrm{N}$ & Mean & St. dev. & $\mathrm{N}$ & & & \\
\hline Attendance & 3,49 & 1,434 & 155 & 3,65 & 1,375 & 190 & 0,066 & 0,602 & 0,194 \\
\hline Class activity & 3,79 & 1,000 & 155 & 3,72 & 1,024 & 190 & $-2,015$ & $-0,935$ & 0,107 \\
\hline Total grades & 75,77 & 21,590 & 155 & 77,79 & 18,429 & 190 & $-0,162$ & $-1,070$ & 0,466 \\
\hline
\end{tabular}

The obtained results show that there is no significant difference in the number of points that students received for attending online (Mean $=3.49$, St. dev. $=1,434)$ and combined classes $($ Mean $=3.65$, St. dev. $=1,375)$. Furthermore, the points that students received for activity during online classes (Mean $=3.79$, St. dev. $=1,000)$ and combined classes (Mean $=3.72$, St. dev. $=1,024)$ were compared, but also, in this case there is no statistically significant difference. Based on the data from the table, it can be concluded that there is no statistically significant difference between the total points in students who attended online classes $($ Mean $=75.77$, St. dev. $=21,590)$ and the number of points in students who attended combined classes $($ Mean $=77.79$, St. dev. $=18.429)$.

Using the chi-square test, a comparison of the distribution of grades of students who attended online and combined classes was performed, and the results are given in Table 4.

Table 4. An overview of the distribution of grades in online and combined teaching

\begin{tabular}{|l|l|c|c|c|c|c|c|c|c|}
\hline \multirow{2}{*}{ Period } & \multicolumn{8}{|c|}{ Grade } \\
\cline { 3 - 9 } & 5 & 6 & 7 & 8 & 9 & 10 & Success & Fall \\
\hline Online & Count & 16 & 26 & 8 & 10 & 15 & 80 & 139 & 16 \\
education & $\%$ & $10,3 \%$ & $16,8 \%$ & $5,2 \%$ & $6,4 \%$ & $9,7 \%$ & $51,6 \%$ & $89,7 \%$ & $10,3 \%$ \\
\hline Combined & Count & 12 & 21 & 17 & 27 & 21 & 92 & 178 & 12 \\
education & $\%$ & $6,3 \%$ & $11,1 \%$ & $8,9 \%$ & $14,2 \%$ & $11,1 \%$ & $48,4 \%$ & $93,7 \%$ & $6,3 \%$ \\
\hline
\end{tabular}

The results of the chi-square test also show that there is no statistically significant difference between the grades obtained by students who followed online classes and students who followed combined classes $(\mathrm{N}=345$, Chi-Square $=10,549, \mathrm{df}=5, \mathrm{p}=0.061)$. Based on the above mentioned, it can be concluded that there is no statistically significant difference between the success of students who attended online classes and the success of students who attended combined classes.

\subsection{Results of the comparison traditional and combined education}

Finally, the success of students who attended traditional classes (160 students) and the success of students who attended combined classes (190 students) were compared, and the results are given in Table 5.

Table 5. Comparison of student success in traditional and combined teaching

\begin{tabular}{|c|c|c|c|c|c|c|c|c|c|}
\hline \multirow{2}{*}{$\begin{array}{l}\text { Assessment } \\
\text { items }\end{array}$} & \multicolumn{3}{|c|}{ Traditional education } & \multicolumn{3}{|c|}{ Combined education } & \multirow{2}{*}{$\begin{array}{c}\text { Difference } \\
\text { mean }\end{array}$} & \multirow{2}{*}{$\begin{array}{l}\mathrm{t} \text {-Test } \\
\text { value }\end{array}$} & \multirow{2}{*}{$\mathrm{p}$ value } \\
\hline & Mean & St. dev. & $\mathrm{N}$ & Mean & St. dev. & $\mathrm{N}$ & & & \\
\hline Attendance & 3,7 & 209 & 160 & 3,65 & & 19 & 0,116 & 0,841 & 0,401 \\
\hline & 3,83 & & 160 & 3,72 & & 190 & & & \\
\hline Total grades & 82,01 & 14,924 & 160 & 77,79 & 18,429 & 190 & 4,217 & 2,365 & 0,019 \\
\hline
\end{tabular}


The obtained results show that there is no statistically significant difference in the number of points that students received for attendance and activity in traditional and combined classes ( $\mathrm{p}$ value $<0.05$ ). However, statistical significance was determined when comparing the total number of points that students achieved by following traditional classes and the number of points that they achieved by following combined classes ( $p$ value $=0.019$ ). The magnitude of the impact was determined using the eta square (eta square $=0.015$ ) and the obtained result shows that the way of teaching has a small effect on student success.

Using the chi-square test, a comparison of the distribution of grades of students who attended traditional and combined classes was performed, and the results are given in Table 6.

Table 6. An overview of the distribution of grades in traditional and combined teaching

\begin{tabular}{|l|l|c|c|c|c|c|c|c|c|}
\hline \multirow{2}{*}{ Period } & \multicolumn{10}{|c|}{ Grade } \\
\cline { 2 - 10 } & 5 & 6 & 7 & 8 & 9 & 10 & Success & Fall \\
\hline Traditional & Count & 8 & 13 & 8 & 22 & 18 & 91 & 152 & 8 \\
education & $\%$ & $5,0 \%$ & $8,1 \%$ & $5,0 \%$ & $13,7 \%$ & $11,3 \%$ & $56,9 \%$ & $95 \%$ & $5,0 \%$ \\
\hline Combined & Count & 12 & 21 & 17 & 27 & 21 & 92 & 178 & 12 \\
education & $\%$ & $6,3 \%$ & $11,1 \%$ & $8,9 \%$ & $14,2 \%$ & $11,1 \%$ & $48,4 \%$ & $93,7 \%$ & $6,3 \%$ \\
\hline
\end{tabular}

Based on the results of the chi-square test, it can be concluded that there is a statistically significant difference between the grades of students who attended traditional and combined classes $(\mathrm{N}=350$, Chi-Square $=4.128, \mathrm{df}=5, \mathrm{p}=0.021)$. The correlation coefficient (Phi coefficient $=0.109$ ) indicates a small impact, that is a weak correlation between students' grades and the way they attended classes. Based on the presented data, it can be concluded that better success was achieved by students who participated traditional classes.

After conducting the overall analysis, it can be concluded that there is a statistically significant difference between the success of students who attended traditional and online classes, and the success of students who attended traditional and combined classes. The best results were achieved by students who attended traditional classes in the classroom. In the following period, it is necessary to use digital technologies and the Internet as powerful tools to improve foreign language teaching, and in order for students to reach the same level of knowledge achieved in traditional teaching (Živković and Stojković 2013). The obtained result was confirmed in previously conducted research which shows that students who participated traditional classes had better results in the final exam (Nyer 2019) (Sintema 2020). On the other hand, the results of most of the conducted research show that the success of students does not depend on the way of teaching (Soesmanto and Bonner 2019) (Lorenzo-Alvarez, et al. 2019) (Said 2021).

\section{CONCLUSION}

Evaluation and comparison of the performance of students who attended traditional classes before the pandemic, online and combined during the pandemic, which was the main goal of the research; showed that students achieved the best success in traditional classes. This is shown by the results of the research, where it is noticeable that the performance of students is better in traditional teaching compared to online and combined teaching, and this can certainly be 
explained by the fact that the students are accustomed to this approach and method of work. The fact is that the real reasons for the obtained result could be explained by additional qualitative empirical research, which is why students who were born and raised in the digital environment, unlike professors who arrived in the digital world in the later years of their lives (Išaretović 2017) traditional way of teaching in classrooms is closer and why they achieve better results working in classrooms "face to face" with professors. Some previous researches show that students are not interested in online learning (e-learning) because it is less enjoyable than traditional learning (Hasan and Bao 2020).

This research should serve as an initial capsule for other private and public faculties in the country and the surrounding area, whose future research would contribute to obtaining short-term and long-term implications of different teaching methods. The integration of online learning in the Education Development Strategy of the Republic of Srpska 2021 2025 , would greatly help to position online learning as an equal way of teaching, with a number of adjustments that are implied. Here it is primarily referred to the design of attractive curricula for online teaching. Classes should not be conducted according to the curriculum of traditional teaching (Lee, Lim and Kim 2016) (Chung and Cheon 2020). Higher education institutions must increase the speed of the Internet connection and constantly update purchased applications for conducting online classes. A special segment of the story is the strengthening of digital literacy among students, and especially among professors, through continuous courses and education so that professors can make the most of all the benefits of online interaction with students. Also, it is the responsibility of professors to instruct students very clearly and specifically in assignments, colloquia and exams during online classes.

Based on the conducted research, some of the recommendations are: curriculum renewal, new curricula, clear and concrete tasks for students, fast and stable internet connection, constant updating of applications and platforms through which online teaching is performed, daily assistance by experts (services) to students and professors during the application process for transferring applications academic content, developing and strengthening of digital literacy among professors and students.

\section{REFERENCES}

Babić, Ž., E. Muhić, and D. Tica. 2021. "Coronavirus discourse of uncertainty in the guise of reassurance: We standa together only when we do not stand apart." The Journal of teaching English for specific and academic purposes 9 (3): 409-420.

Bozkurt, A., I. Jung, J. Xiao, and et al. 2020. "A global outlook to the interruption of education due to Covid-19 pandemic: navigating in a time of uncertainty and crisis." Asian Journal of Distance Education 15 (1): 1-126.

Cavanaugh, J., and S. J. Jacquemin. 2015. "A large sample comparison of grade based student learning outcomes in online vs. face-to-face courses." Online learning 19 (2).

Chung, S., and J. Cheon. 2020. "Emotional design of multimedia learning using background images with motivational cues." Journal of Computer Assisted Learning 36: 922-932.

Doshi, P. 2011. The elusive definition of pandemic influenza. Bulletin of World Health Organization, World Health Organization, 532-538. 
Dušanić - Gačić, S., and Z. Agić. 2021. "Finansiranje obrazovanja tokom pandemije Covid19." Časopis za društvena pitanja Aktuelnosti (Banja Luka College) 39: 81-90.

Đurović, V. 2021. „Methods of the teaching of a foreign language for specific purposes in higher education institutions." Conference proceedings Accounting and audit in theory and practice. Banja Luka: Banja Luka College, Besjeda. 289-296.

Halilović, N. 2020. Online didaktika. Sarajevo: Uprava za obrazovanje i nauku Rijaseta Islamske zajednice u BiH i Medija centar Rijaseta Islamske zajednice.

Hasan, N., and Y. Bao. 2020. "Impact of "e-Learning crack-up" perception on psychologic distress among college students during Covid-19 pandemic: A mediating role of "fear of academic year loss"." Chil Youth Serv Rev.

Hjelsvold, R., A. Bahmani, and M. Loras. 2020. "First impressions" from educators as NTNU transitions to an online only mode of learning. https://www.researchgate.net/publication/ 341042510.

Hui, D.S., E.I. Azhar, T.A. Madani, F. Ntoumi, R. Kock, O. Dar, G. Ippolito, T.D. Mchugn, Z.A. Memish, and C. Drosten. 2020. "The countinuing 2019nCoV epidemic threat of novel coronaviruses to global health - The latest 2019 novel coronavirus outbreak in Wuhan, China." International Journal of Infectious Diseases 91: 264-266.

Išaretović, S. 2017. Pismenost za novo doba. Banja Luka: Banja luka College, Besjeda.

Kurilovas, C., and S. Kubilinskiene. 2020. "Lithuanian case study on evaluating suitability, acceptance and use of IT tools by students - An example of applying Technology Enhanced Research methods in higer education." Computera in Human Behavior 107.

Lee, J., C. Lim, and H. Kim. 2016. "Development of an instructional design model for flipped learning in higher education." Educational Technology Research and Development 103: 427-453.

Lorenzo-Alvarez, R., T. Rudolphi-Solero, M. J. Ruiz-Gomez, and F. Sendra-Portero. 2019. "Medical student education for abdominal radiographs in a 3D virtual classrom versus traditional classrom: a rondomized controlled trial." American Journal of Roentgenology 2013 (3): 644-650.

Ma, J. 2020. "Coronavirus: China's First Confirmed Covid-19 Case Traced back to November 17." South China Morning Post. March 13. Accessed March 10, 2021. https://www.scmp.com/news/china/society/article/3074991/coronavirus-chinas-firstconfirmed-covid-19-case-traced-back.

Murgatrotd, S. 2020. „Covid-19 and Online learning.“ Alberta. doi:10.13140/RG.2.2.31132. 85120.

Nyer, P. 2019. "The relative effectiveness of online lecture methods on student test scores in a business course." Open Journal of Business and Management 7 (4): 1648-1656.

Said, G. R. E. 2021. „How Did the Covid-19 Pandemic Affect Higher Education Learning Experience? An Empirical Investigation of Learners' Academic Performance at a University in a Developing Country." Advances in Human - Computer Interaction (Hindawi).

Sintema, E. J. 2020. „Effect of Covid-19 on the performance of grade 12 students: Implications for STEM education." EURASIA Journal of Mathematics, Science and Technology Education 16 (7): 1-6.

Soesmanto, T., and S. Bonner. 2019. "Dual mode delivery in an introductory statistics course: design and evaluation." Journal of Statistics Education 27 (2).

Stawicki, S.P., R. Jeanmonod, A.C. Miller, L. Paladino, D.F. Gaieski, A.Q. Yaffee, Al. De Wulf, J. Grover, T.J. Papadimos, and C. Bloem. 2020. "The 2019-2020 novel coronavirus (severe scute respiratory syndrome coronavirus 2) pandemic: A joint American college of 
academic international medicine - world academic council of emergency medicine multidisciplinary COVID-19 working group consensus paper." J. Glob. Infect. Dis. 12: 47.

Tan, J., H. Du, C. L. Jan, and R. Lin. 2019. "Contributing factors on the effectiveness of delivering business technology courses: on-ground versus online." International Journal of Accounting and Financial Reporting 9 (4): 19-40.

Trnavac, N., and J. Đorđević. 2013. Pedagogija. Beograd: Naučna KMD.

United Nations. 2020. „Policy Brief: Education during Covid-19 and Beyond.“

World Bank. 2020. Covid-19 Could Lead to Permanent Loss in Learning and Trillions of Dollars in Lost Earnings. June. Accessed February 12, 2021. https://www.worldbank. org/en/news/press-release/2020/06/18/covid-19-could-lead-to-permanent-loss-in-learningand-trillions-of-dollars-in-lost-earnings.

Yusuf, B. N. 2020. „Are we prepared enough? A case study of challenges in online learning in a private higher learning institution during the Covid-19 outbreaks." Advances in Social Science Research Journal 7: 205-212.

Zovko, V. 2014. „Long range prospect of education - from now until singularity.“ Interdisciplinary Description of Complex Systems 12 (2): 161-175.

Živković, S., and N. Stojković. 2013. "To modernize or not to modernize - There is no question." Academic Journal of Interdisciplinary Studies 2 (11): 70-76. 